University of Nebraska - Lincoln

DigitalCommons@University of Nebraska - Lincoln

Agronomy \& Horticulture -- Faculty Publications

Agronomy and Horticulture Department

1967

\title{
Trans-o-Hydroxycinnamic Acid Glucosylation in Cell-Free Extracts of Melilotus alba
}

\author{
A. Kleinhofs \\ University of Nebraska-Lincoln \\ Francis A. Haskins \\ University of Nebraska-Lincoln, fhaskins@neb.rr.com \\ Herman J. Gorz \\ University of Nebraska-Lincoln
}

Follow this and additional works at: https://digitalcommons.unl.edu/agronomyfacpub

Part of the Plant Sciences Commons

Kleinhofs, A.; Haskins, Francis A.; and Gorz, Herman J., "Trans-o-Hydroxycinnamic Acid Glucosylation in Cell-Free Extracts of Melilotus alba" (1967). Agronomy \& Horticulture -- Faculty Publications. 176. https://digitalcommons.unl.edu/agronomyfacpub/176

This Article is brought to you for free and open access by the Agronomy and Horticulture Department at DigitalCommons@University of Nebraska - Lincoln. It has been accepted for inclusion in Agronomy \& Horticulture -Faculty Publications by an authorized administrator of DigitalCommons@University of Nebraska - Lincoln. 


\title{
TRANS- $o$-HYDROXYCINNAMIC ACID GLUCOSYLATION IN CELL-FREE EXTRACTS OF MELILOTUS ALBA*
}

\author{
A. Kleinhofs, F. A. Haskins and H. J. Gorz \\ Department of Agronomy, University of Nebraska, Lincoln, Nebraska, U.S.A.
}

(Received 4 April 1967)

\begin{abstract}
The glucosylation of trans-o-hydroxycinnamic acid has been demonstrated in cell-free extracts of Melilotus alba. The reaction requires UDPG, a sulfhydryl compound, and an active extract from sweet clover leaves. The product of the reaction has been tentatively identified as trans- $\beta$-D-glucosyl-o-hydroxycinnamic acid.
\end{abstract}

\section{INTRODUCTION}

Low molecular weight phenols which occur in living cells are normally present in a combined form. ${ }^{1}$ Synthesis of the combined form often involves the linking of the hydroxyl group of the phenol to a D-glucose molecule. Limited information regarding the enzymes that catalyze this type of conjugation is available. Yamaha and Cardini ${ }^{2}$ obtained an enzyme from wheat germ which catalyzed the formation of arbutin (hydroquinone- $\beta$-D-glucoside) from hydroquinone and uridine diphosphate glucose (UDPG). The enzyme was relatively nonspecific since a large number of di- and tri-phenols served as substrates, but it did not attack monophenols. Insect tissues also are a source of enzymes which can catalyze the formation of arbutin from hydroquinone and UDPG. ${ }^{3,4}$

Barber $^{5,6}$ described the enzymatic glycosylation of quercetin $\left(3,3^{\prime}, 4^{\prime}, 5,7\right.$-pentahydroxyflavone) to form rutin (quercetin-3-O- $\alpha$-L-rhamnosyl-( $1 \rightarrow 6)-\beta$-D-glucoside). Extensive in vivo and in vitro experiments led Pridham and Saltmarsh ${ }^{7}$ to conclude that the glucosylation of mono-, di-, and tri-hydric phenols produces primarily the corresponding mono- $\beta$-glucosides. They, however, did not exclude the formation of oligoglucosides or glucosylation of more than one hydroxyl group. Pridham ${ }^{8}$ examined the ability of various plant tissues to convert quinol and resorcinol to the corresponding mono- $\beta$-D-glucopyranosides in vivo. This activity was prominent in the angiosperms and gymnosperms, but appeared entirely absent in the algae and fungi.

More recently, Corner and Swain ${ }^{9}$ reported the formation of glucose esters of $p$-coumaric,

* Cooperative investigations of the Crops Research Division, Agricultural Research Service, United States Department of Agriculture, and the Nebraska Agricultural Experiment Station. Supported in part by The National Science Foundation (Grant No. GB-1148). Published with the approval of the Director as Paper No. 2065, Journal Series, Nebraska Agricultural Experiment Station.

1 J. B. HARBorne (Editor), Biochemistry of Phenolic Compounds, Chap. 4. Academic Press, New York (1964).

2 T. Yamaha and C. E. Cardini, Arch. Biochem. Biophys. 86, 127 (1960).

${ }^{3}$ G. J. Dutron and A. M. Duncan, Biochem. J. 77, 18P (1960).

4 J. C. Trivelloni, Arch. Biochem. Biophys. 89, 149 (1960).

${ }^{5}$ G. A. BARBER, Biochemistry 1, 463 (1962).

${ }^{6}$ G. A. Barber, Biochem. Biophys. Res. Commun. 8, 204 (1962).

7 J. B. Pridham and M. J. Saltmarsh, Biochem. J. 87, 218 (1963).

8 J. B. Pridham, Phytochem. 3, 493 (1964).

9 J. J. CORNER and T. SWAIN, Nature 207, 634 (1965). 
caffeic, ferulic, and sinapic acids upon incubation of an acetone powder prepared from leaves of geranium (Geranium zonale cv. "Paul Crampel") with UDPG at pH 8.4 and $37^{\circ}$. No esters were detected at $\mathrm{pH} 5.7$ or 7.4 , but esters were formed in small quantities at $\mathrm{pH} 9.4$ and 10.4 . No glucosides were formed from the hydroxycinnamic acids in this experiment.

Sweet clover (Melilotus alba Desr.) plants of the $\mathrm{CuCu}$ genotype contain large amounts of $o$-coumaric acid glucoside and coumarinic acid glucoside, the trans- and cis-isomers, respectively, of $\beta$-D-glucosyl-o-hydroxycinnamic acid. ${ }^{10}$ Experiments with sweet clover ${ }^{11,12}$ and Hierochloe odorata ${ }^{13}$ have shown that when $o$-coumaric acid is administered to these plants in vivo it is rapidly converted to its $\beta$-glucoside. Kosuge and Conn ${ }^{11}$ referred to unpublished observations which indicated that the synthesis of $o$-coumaric acid glucoside occurred in reaction mixtures containing 0 -coumaric acid, UDPG, and a cell-free extract from white sweet clover shoots. Further information about the enzymatic catalysis of this reaction has not been found in the literature to date.

\section{RESULTS AND DISCUSSION}

\section{Identification of the Product of the Reaction}

Crude enzyme preparation $(0.4 \mathrm{ml})$ was incubated with $0.756 \mu$ moles $o$-coumaric acid- $\beta$ ${ }^{14} \mathrm{C}$ (sp. act. 0.091 $\mu \mathrm{c} / \mu$ mole), $2 \cdot 0 \mu$ moles UDPG, $50 \mu$ moles $\mathrm{KH}_{2} \mathrm{PO}_{4}$ buffer, and $25 \mu$ moles $\beta$-mercaptoethanol in a total volume of $2.0 \mathrm{ml}$ at $\mathrm{pH} 7.4$ for $4 \mathrm{hr}$ at $30^{\circ}$. The reaction was stopped by adding $2 \mathrm{ml}$ methanol. The resulting suspension was centrifuged to remove the precipitate and the supernatant fraction was reduced to a small volume under a stream of air at room temperature. This concentrated solution was examined by paper chromatography and found to contain, in addition to free $o$-coumaric acid, a radioactive spot with $R_{f}$ identical to authentic $o$-coumaric acid glucoside in $2 \%$ acetic acid (Solvent $\mathrm{A}$ ), $n$-propanol-conc. $\mathrm{NH}_{4} \mathrm{OH}-\mathrm{H}_{2} \mathrm{O}(8: 1: 1, \mathrm{v} / \mathrm{v} / \mathrm{v})$ (Solvent $\mathrm{B}$ ), and $n$-butanol-glacial acetic acid- $\mathrm{H}_{2} \mathrm{O}(4: 1: 5, \mathrm{v} / \mathrm{v} / \mathrm{v}$, upper phase) (Solvent $C$ ). When the chromatogram was sprayed with emulsin $(5 \mathrm{mg} / \mathrm{ml})$, a fluorescent spot appeared corresponding exactly with the radioactive spot. The color of the fluorescence appeared identical to that of $o$-coumaric acid. The residual $o$-coumaric acid, and the spot tentatively identified as $o$-coumaric acid glucoside, were the only radioactive peaks detected on the chromatogram with the exception of one very small peak. This small peak was later shown to occur as a result of a nonenzymatic reaction between $o$-coumaric acid and, probably, $\beta$-mercaptoethanol. Under the standard assay conditions the nonenzymatic reaction was not detected.

To determine whether the glucose ester of $o$-coumaric acid was a product of the reaction, mixtures with increased $o$-coumaric acid, UDPG and enzyme levels were incubated at $\mathrm{pH}$ $7 \cdot 5$ and $8 \cdot 3$. The reaction products were examined by paper chromatography. Spraying with emulsin revealed only one spot with the fluorescence of $o$-coumaric acid. Emulsin would be expected to hydrolyze both the glucose ester and the $\beta$-glucoside of $o$-coumaric acid. ${ }^{14}$

To determine if the ester could be a minor product that did not separate from the glucoside with the solvents used, portions of the reaction mixtures were streaked on Whatman No. 3 paper and developed in solvent $B$ alongside authentic $o$-coumaric acid glucoside. The band corresponding to the glucoside was eluted and the absorption spectrum determined over a

10 F. A. Haskins and H. J. Gorz, Biochem. Biophys. Res. Commun. 6, 298 (1961).

11 T. Kosuge and E. E. ConN, J. Biol. Chem. 234, 2133 (1959).

12 F. A. Haskins and T. Kosuge, Genetics 52, 1059 (1965).

13 S. A. Brown, G. H. N. Towers and D. WrIGHT, Can. J. Biochem. Physiol. 38, 143 (1960).

14 J. B. HARBorne and J. J. CoRner, Biochem. J. 81, 242 (1961). 
range of $230-350 \mathrm{~nm}$ in $0.05 \mathrm{~N} \mathrm{HCl}$ and $0.05 \mathrm{~N} \mathrm{NaOH}$. Although there was considerable contamination as evidenced by high absorption at the lower wavelengths ( $250 \mathrm{~nm}$ and shorter), the $\lambda_{\max }$ of the eluates corresponded exactly with that of authentic $o$-coumaric acid glucoside. Furthermore, the spectra of the eluates showed the same characteristic hypsochromic shift as the authentic $o$-coumaric acid glucoside sample with change from acid to alkali conditions. There was no indication of the bathochromic shift typical of cinnamic acid esters on changing from acid to alkali conditions. ${ }^{14}$

The participation of coumarinic acid or its glucoside was investigated by using an incubation mixture in which standard assay volumes were multiplied by four. For this experiment the crude enzyme preparation was precipitated with $\left(\mathrm{NH}_{4}\right)_{2} \mathrm{SO}_{4}(40-60 \%$ sat.), and the precipitate was washed with $\left(\mathrm{NH}_{4}\right)_{2} \mathrm{SO}_{4}(70 \%$ sat.) to remove the endogenous $o$-hydroxycinnamic acid compounds. The samples were assayed for $o$-coumaric and coumarinic acids and their glucosides. No free or glucosidically bound coumarinic acid was detected over a 4-hr incubation period. Decrease in content of $o$-coumaric acid corresponded almost exactly with the increase in the content of $o$-coumaric acid glucoside (Fig. 1).

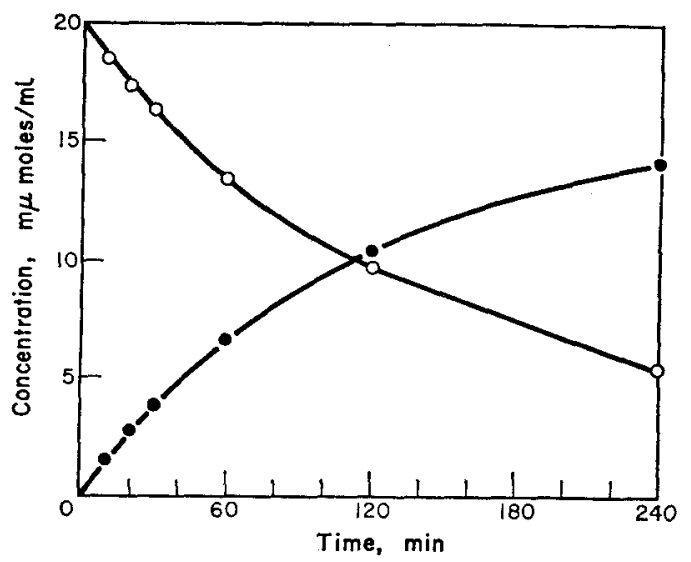

FIG. 1. CONTENT of FReE 0 -COUMARIC ACID $(0-0)$ AND 0 -COUMARIC ACID GLUCOSIDE $\bullet(-\bullet)$ IN THE REACTION MIXTURE AT VARIOUS TIMES.

\section{Properties of the Enzyme}

Effect of $p H$. The optimum $\mathrm{pH}$ of this reaction was 7-6-8.3 (Fig. 2). The rate of reaction dropped sharply on the alkaline side indicating probable inactivation of the enzyme. Below pH 6.0 considerable nonenzymatic loss of $o$-coumaric acid was observed, particularly in acetate buffers. This loss is thought to be due to the reaction of $o$-coumaric acid with $\beta$-mercaptoethanol. The nonenzymatic reaction was not detected over the rest of the $\mathrm{pH}$ range.

Effect of enzyme concentration and duration of reaction. Preliminary experiments had shown that a large excess of UDPG was needed for maximum reaction rate with the crude enzyme preparations. To reduce the consumption of UDPG, standard assay conditions were chosen in which the substrate (o-coumaric acid) concentration was considerably below the saturation level. Within the range of 0.2 to $0.8 \mathrm{~m} \mu$ mole of $o$-coumaric acid consumed per minute the reaction rate was proportional to the amount of enzyme preparation added. The reaction was linear with time up to $20 \mathrm{~min}$ after addition of the enzyme. 


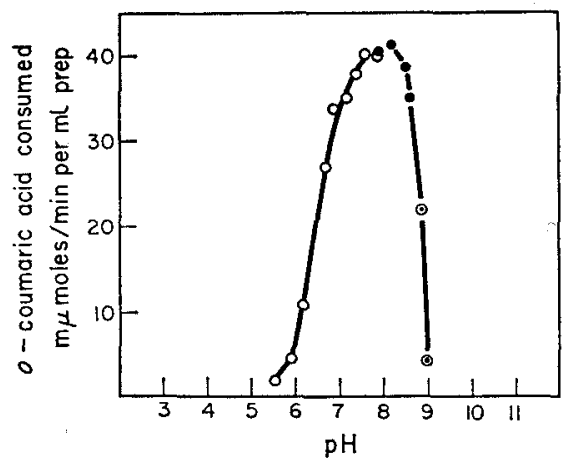

Fig. 2. Effect of pH on reaction velocity. Concentrations were equivalent to those used IN THE STANDARD ASSAY. THE VALUES WERE OBTAINED IN POTASSIUM PHOSPHATE BUFFER (O); Tris-HCl BUFFER (๑); AND SODIUM BORATE BUFFER $(\odot)$.

Effect of sulfhydryl compounds. The effect of $\beta$-mercaptoethanol on the enzyme velocity is shown in Fig. 3. The plateau was not reached until substantial quantities of $\beta$-mercaptoethanol were added. If $\beta$-mercaptoethanol was left out of the buffer used in making the enzyme preparation, no enzyme activity was detected in the extract. Attempts were made to replace the $\beta$-mercaptoethanol used in the standard assay with equal concentrations of other reducing compounds. Ascorbic acid and glutathione were completely ineffective and cysteine was approximately equal to $\beta$-mercaptoethanol in effectiveness.

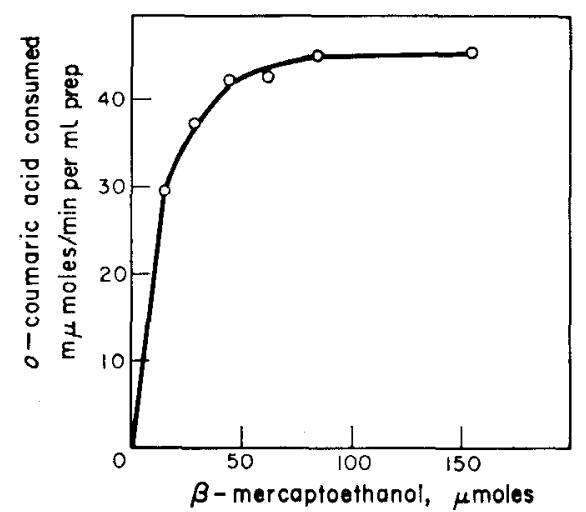

Fig. 3. EFFECT OF $\beta$-MERCAPTOETHANOL CONCENTRATION ON REACTION VELOCITY. WHEN $\beta$-MERCAPTOETHANOL WAS LEFT OUT OF THE GRINDING BUFFER, NO ENZYME ACTIVITY COULD BE DETECTED.

Inhibitors. Of the metal ions tested, $\mathrm{Cu}^{++}\left(\mathrm{CuCl}_{2}\right)$ and $\mathrm{Zn}^{++}\left(\mathrm{ZnSO}_{4}\right)$ at $10^{-3} \mathrm{M}$ final concentration inhibited the enzyme 63 and 77 per cent respectively. $\mathrm{Hg}^{++}\left(\mathrm{HgCl}_{2}\right)$ and $\mathrm{Ag}^{+}$ $\left(\mathrm{Ag}_{2} \mathrm{SO}_{4}\right)$ at $10^{-5} \mathrm{M}$ concentration were ineffective, probably due to the reaction of these ions with the excess $\beta$-mercaptoethanol in the reaction mixture. Ethylenediaminetetracetic acid tetrasodium salt (EDTA) at $4 \times 10^{-3} \mathrm{M}$ final concentration was not inhibitory, but sodium citrate at the same concentration inhibited the enzyme 37 per cent. o-Coumaric acid glucoside was not inhibitory at $8 \times 10^{-4} \mathrm{M}$ final concentration.

Specificity. Enzyme specificity has not been investigated in detail, but in incubation mixtures containing coumarinic acid $-\beta-{ }^{14} \mathrm{C}$ (coumarin-3- ${ }^{14} \mathrm{C}$ dissolved in $0.05 \mathrm{~N} \mathrm{NaOH}$ ) as the substrate, coumarinic acid glucoside was not detected. 
Enzyme stability. The enzyme preparations lost glucosylating activity rapidly when stored. This lability has hampered attempts to purify the enzyme. Storage at $4^{\circ}$ resulted in loss of all enzyme activity in 1 or 2 days. Freezing resulted in 100 per cent loss in activity and dialysis overnight inactivated the enzyme. Fresh plant samples could be ground in liquid nitrogen and stored in the freezer without apparent loss of activity. Some acetone powder preparations possessed enzyme activity, but others did not.

\title{
Discussion
}

The probable function of this enzyme in vivo is the glucosylation of $o$-coumaric acid and possibly other phenols. In recent years several phenol glucosylating enzymes have been reported from plant as well as animal tissues. These were briefly reviewed in the introduction. All of these enzymes share a characteristic lability and have been only partially purified and characterized. The $o$-coumaric acid glucosylating system in sweet clover has the advantages that a sensitive quantitative assay is possible and the system utilizes a natural substrate. Furthermore, the glucosylation by this enzyme of $o$-coumaric acid but not coumarinic acid fits into the general pathway of coumarin biosynthesis. ${ }^{15}$

\section{EXPERIMENTAL PROCEDURE}

\section{Source of Plant Material}

Sweet clover plants of $c u c u b b$ genotype were used in this study. The derivation, attributes, and culture of this genotype have been described. ${ }^{16}$

\section{Enzyme Preparations}

Crude enzyme preparations were made by grinding with sand plant tissue in cold $0.1 \mathrm{M}$ Tris- $\mathrm{HCl}$ buffer, pH $8.0(10 \mathrm{ml} / \mathrm{g})$, containing $0.15 \mathrm{M} \beta$-mercaptoethanol and $1 \%$ Polyclar AT. Further dilution before centrifugation was made with the same buffer minus the Polyclar AT. For very young leaves this dilution was tenfold. The homogenates were centrifuged at $20,000 \mathrm{~g}$ for $15 \mathrm{~min}$ at $0^{\circ}$ and supernatant fractions assayed immediately. These fractions contained more than 90 per cent of the total activity detected.

\section{Assay Procedure}

The activity of the enzyme was determined by measuring the decrease in content of $o$-coumaric acid in the reaction mixture during a measured time period. The reaction mixture contained enzyme, $0.05 \mu$ mole $o$ coumaric acid, $1.0 \mu$ moles UDPG, $115 \mu$ moles Tris buffer, $\mathrm{pH} \mathrm{8.0,} \mathrm{and} 85 \mu$ moles $\beta$-mercaptoethanol in a total volume of $2.5 \mathrm{ml}$. The reaction mixture was incubated in open test-tubes at $30^{\circ}$, and 0.5 and $15.5 \mathrm{~min}$ after addition of the enzyme $0.5-\mathrm{ml}$ aliquots were withdrawn and pipetted into $4.5 \mathrm{ml}$ of $2.5 \mathrm{~N} \mathrm{NaOH}$ to stop the reaction. $o$-Coumaric acid content was determined using the fluorometric assay of Haskins and Gorz. ${ }^{10}$

\begin{abstract}
Reagents
The $o$-coumaric acid- $\beta-{ }^{14} \mathrm{C}$ (sp. act. $0.091 \mu \mathrm{c} / \mu$ mole) was prepared from coumarin-3- ${ }^{14} \mathrm{C}$ by the following procedure. The coumarin-3-14 $\mathrm{C}(1.9 \mathrm{mg})$ was dissolved by mild heating in $2.0 \mathrm{ml} 2.5 \mathrm{~N} \mathrm{NaOH}$ and this solution was diluted to 10 volumes with $\mathrm{H}_{2} \mathrm{O}$. The resulting solution was irradiated with u.v. light $(360 \mathrm{~nm})$ for $2 \mathrm{hr}$, acidified to $\mathrm{pH} 2.0$ with 2 and $0.2 \mathrm{~N} \mathrm{HCl}$, and allowed to stand for approximately $5 \mathrm{~min}$. It was then carefully neutralized with $2.5 \mathrm{~N} \mathrm{NaOH}$ and brought to $\mathrm{pH} 8.0$ with $0.05 \mathrm{~N} \mathrm{NaOH}$. It is important that the solution not be allowed to become basic enough to break the lactone ring of coumarin. The resulting solution (approximately $20 \mathrm{ml}$ ) was extracted with three $10-\mathrm{ml}$ portions of anhydrous ether to remove the residual coumarin. The aqueous phase was then acidified to $\mathrm{pH} 2 \cdot 0$ with $2 \mathrm{~N} \mathrm{HCl}$ and extracted with three $10-\mathrm{ml}$ portions of ether to recover the $o$-coumaric acid. The ether phase was evaporated to dryness and the residue taken up in a small volume of $0.05 \mathrm{~N} \mathrm{NaOH}$. Yield of $o$-coumaric acid was 77 per cent. Examination of the product by paper chromatography in solvents $A, B, C$ and benzene: glacial acetic acid: $\mathrm{H}_{2} \mathrm{O}(1: 1: 2, \mathrm{v} / \mathrm{v} / \mathrm{v}$, upper phase $)$ revealed only one radioactive spot. This spot corresponded with authentic o-coumaric acid in $R_{f}$ and in color of fluorescence.
\end{abstract}

15 S. A. Brown, Lloydia 26, 211 (1963).

${ }^{16}$ A. Kleinhofs, F. A. Haskins and H. J. Gorz, Plant Physiol. 41, 1276 (1966). 
The coumarin-3-14 C was the generous gift of Dr. T. Kosuge, University of California, Davis, California. $o$-Coumaric acid glucoside was synthesized from helicin and malonic acid according to the procedure of Helferich and Lutzmann. ${ }^{17}$ Purity was ascertained by determination of melting point and absorption spectrum.

UDPG, glutathione, and L-cysteine were purchased from Sigma Chemical Co. and $\beta$-mercaptoethanol from Eastman Chemical Co. Polyclar AT was the product of General Aniline and Film Corporation (Batch No. 120), and Emulsin was obtained from Mann Research Laboratories.

Other chemicals were reagent grade and obtained from usual commercial sources.

17 B. Helferich and H. Lutzmann, Ann. Chem. 537, 11 (1938). 